\begin{tabular}{|c|c|c|}
\hline Iba pengueress & $\begin{array}{c}\text { Tarım Bilimleri Dergisi } \\
\text { Tar. Bil. Der. }\end{array}$ & Journal of Agricultural Sciences \\
\hline $3 \times 24$ & $\begin{array}{c}\text { Dergi web sayfası: } \\
\text { www.agri.ankara.edu.tr/dergi }\end{array}$ & $\begin{array}{c}\text { Journal homepage: } \\
\text { www.agri.ankara.edu.tr/journal }\end{array}$ \\
\hline
\end{tabular}

\title{
Assessment of Soil Quality Index for Tea Cultivated Soils in Ortaçay Micro Catchment in Black Sea Region
}

\author{
Orhan DENGİZ ${ }^{a}$, Serkan İÇ ${ }^{b}$, Fikret SAYGIN ${ }^{b}$, Ali İMAMOĞLU \\ ${ }^{a}$ Ondokuz Mayls University, Agricultural Faculty, Plant Nutrition and Soil Science Department, Samsun, TURKEY

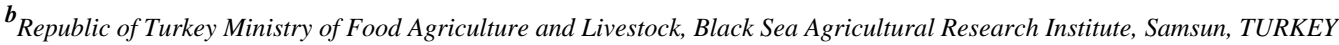

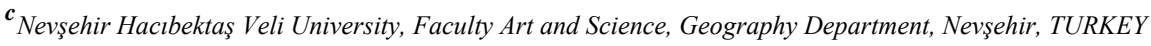

\section{ARTICLE INFO}

Research Article

Corresponding Author: Orhan DENGiZ, E-mail: odengiz@omu.edu.tr, Tel: +90 (0505) 4383353

Received: 10 October 2018, Received in Revised Form: 26 November 2018, Accepted: 28 November 2018

\section{AUTHORS ORCID ID}

(Orhan DENGIZ: 0000-0002-0458-6016), (Serkan İÇ: 0000-0001-6976-762X), (Fikret SAYGIN: 0000-0001-7771-806X), (Ali İMAMOĞLU: 0000-0001-9197-1029)

\section{ABSTRACT}

The objective of this research was to determine soil quality by taking into consideration the integrated Soil Quality Index $\left(\mathrm{SQI}_{\mathrm{w}}\right)$ model on tea plantations located in Ortaçay Micro Catchment of Rize. In the $\mathrm{SQI}_{\mathrm{w}}$ model, soil indicators were weighted by means of the Analytical Hierarchy Process (AHP). Various indicator units were normalized by a Standard Scoring Function. A total of 22 soil quality indicators were included in the $\mathrm{SQI}_{\mathrm{w}}$ model by grouping into
4 criteria which are; i-soil physical properties, ii- soil chemical properties, iii-macronutrient elements, ivmicronutrient elements. Twenty eight soil samples were collected from tea cultivated gardens including dominantly Leptosol and Alisol-Acrisol great soil groups based on FAO/WRB classification. The results indicated that $25 \%$ of the soil samples studied had weak quality level, whereas $75 \%$ were in moderate $\mathrm{SQI}_{\mathrm{w}}$ class in terms of tea requirements of the soil quality.

Keywords: Soil quality index; Analytical Hierarchy Process; Tea plant; Soil indicators

(C) Ankara Üniversitesi Ziraat Fakültesi

\section{Introduction}

Turkey is one of the most significant and unique countries in the World for producing tea plant (Camellia sinensis L.) and it is ranked as the fifth largest producer among the World's tea production (FAO 2009). Tea production is generally located in about $35 \mathrm{~km}$ narrow strip along a coast in the north-eastern Black Sea Region spanning roughly $180 \mathrm{~km}$ from Hopa near the border of Georgia to Araklı township of Trabzon (Müftüoğlu 1987; Özyazıc1 et al 2011). Approximately 76000 ha of soils are involved in tea cultivation, in provinces Artvin (11\%), Rize (65\%), Trabzon (21\%), Giresun and Ordu (3\%) (Müftüoğlu et al 2010). However, west part of the Araklı (Trabzon) located on poor soil quality area is not suitable for tea production due to economic feasibility (Müftüoğlu 1987). Therefore, in order to get optimum growth conditions for tea planting and good yields, well permeable deep soils are required; with organic matter content $>2 \%$ and soil reaction from 4.5 to 5.5 . Groundwater level should be deeper than $90 \mathrm{~cm}$. Soil compaction in subsoil affects root development of the tea plants and causes their susceptibility to 
draught/waterlogging in dry/wet periods. Thus hard pans in the subsoil should be absent down to $2 \mathrm{~m}$ (Özcan et al 2017).

Originally, soil quality was defined as the capacity of a particular soil to sustainably function within particular ecosystem, either natural or managed, and its assessment is a tool in order to support plant growth while maintaining environmental quality and productivity (Doran \& Parkin 1994; Karlen et al 2001). In several studies, soil quality indicators used for assessment of the soil quality are various physico-chemical and biological soil properties, sensitive to disturbance (Gülser 2004; Candemir \& Gülser 2011; Gülser et al 2015; Demir \& Gülser 2015).

These heterogeneous properties are utilized using numerical quality indices. Multiplicative, additive or weighted mean procedures are employed in integration of unitless parameters (gained by normalization)

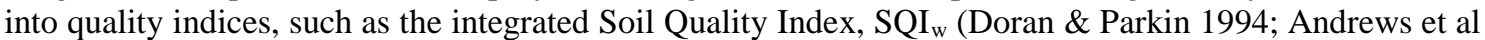
2002; Qi et al 2009). The $S Q I_{w}$ synthesizes the weights (equal for each indicator) of all selected indicators into the resulting index in a formula which utilizes a simple scoring system. Objective of this study was to determine soil quality by using the integrated Soil Quality Index model on tea plantations in micro catchment located in Rize province of the Black Sea Region.

\section{Material and Methods}

\subsection{The study field}

The research area covering about $170 \mathrm{~km}^{2}$ is located in Ortaçay Catchment, which extends from 4527000 to $4545000 \mathrm{~N}$ and from 633000 to $645000 \mathrm{E}$ (UTM, 37 Zone m) in eastern highland Black Sea Region of Turkey (Figure 1).

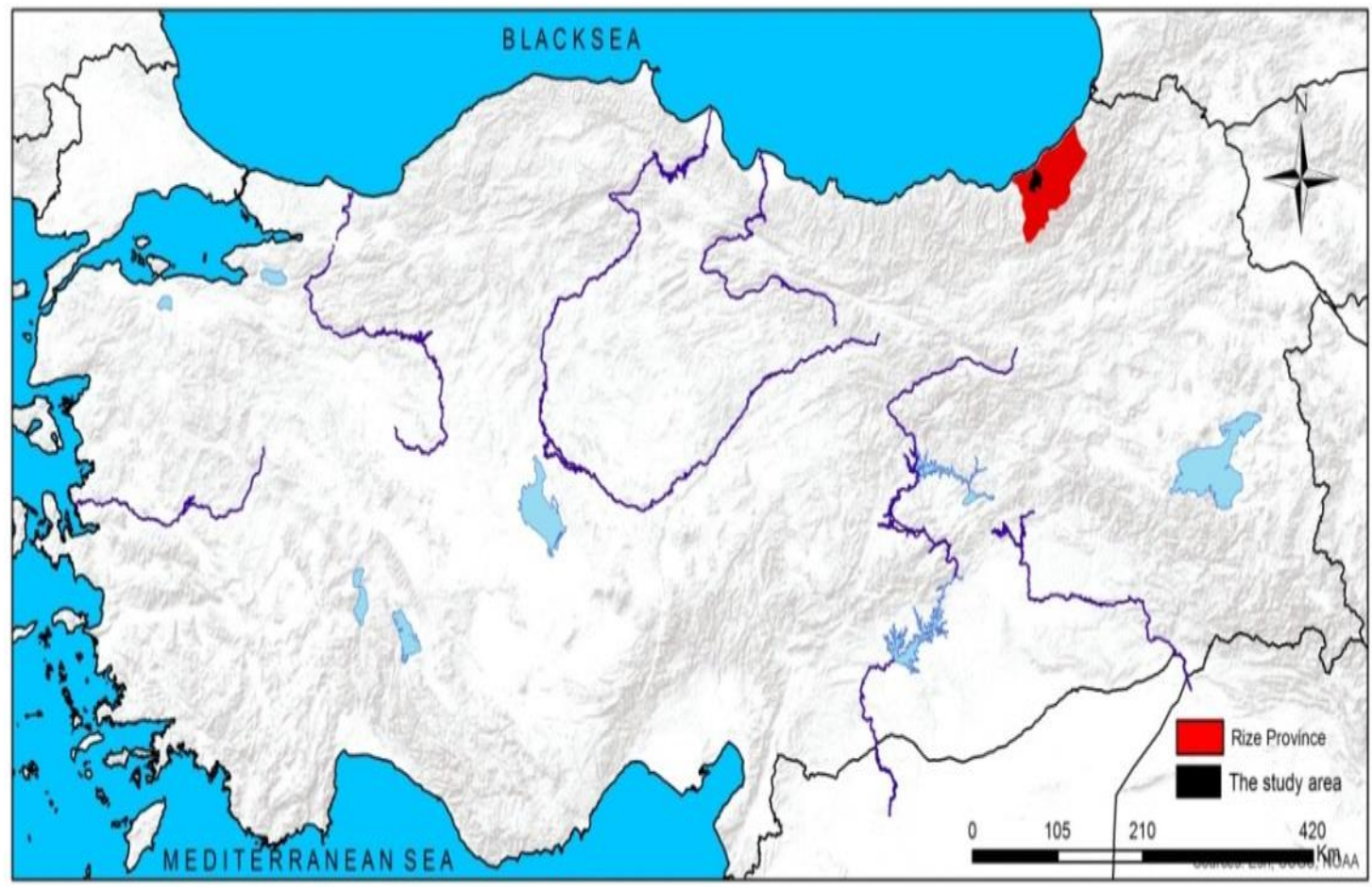

Figure 1- Location of the study area

The catchment lies at an elevation above the sea level from 70 to $1972 \mathrm{~m}$. The study area has different topographic features such as hilly, rolling, flat, etc. Only $7.2 \%$ of the total area is almost flat (Figure 2). Most of the total area corresponding with 11978 ha has more than $15 \%$ slope.

Tarım Bilimleri Dergisi - Journal of Agricultural Sciences 26 (2020) 42-53 
In addition, as for aspect of the study area, in general the southerly (south-easterly, south-westerly) and northerly (north easterly, north westerly) aspects prevail. In the region, the current climate can be called as semi-humid based on the meteorological data covering the period between years 1981-2011. In addition, average annual precipitation and temperature of the study area are $2304.1 \mathrm{~mm}$ and $14.3{ }^{\circ} \mathrm{C}$, respectively.
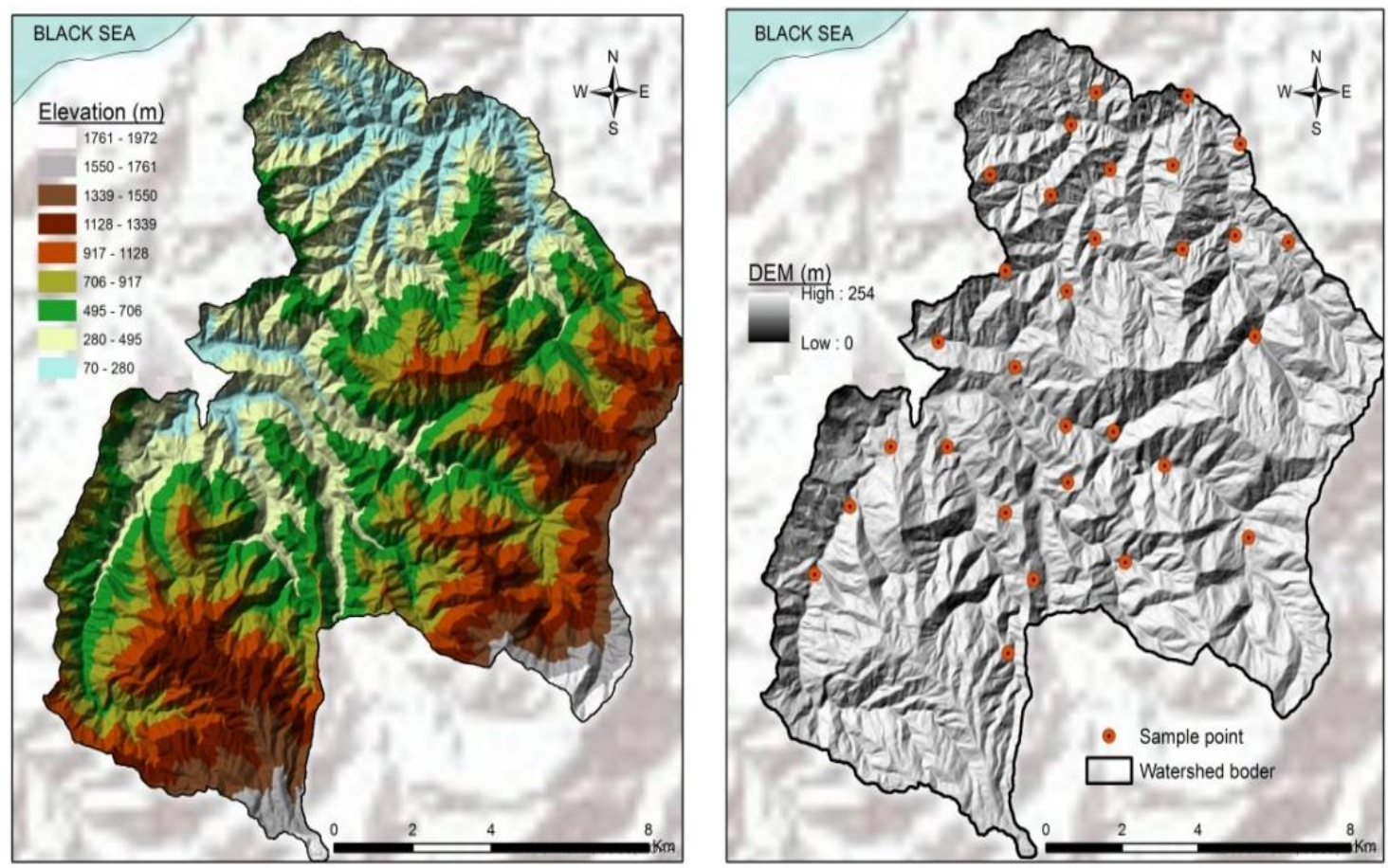

Figure 2- Elevation and hillshade maps of the study area

\subsection{Sampling and indicator scoring}

Field study was conducted in 2017. In total 28 soil samples from Leptosol and Alisols-Acrisols soil units were taken on tea gardens of the Ortaçay Catchment. The sampling was carried out after harvest in the autumn between two cropping seasons in order to reduce the influence of agricultural practices during the growing season, i.e. fertilization. Soil samples were taken from soil surface layer $(0-20 \mathrm{~cm})$ and their coordinates were recorded using GPS device (Figure 2). A total of 22 soil quality indicators were determined and included in the $\mathrm{SQI}_{\mathrm{w}}$ model by grouping into 4 criteria which are; i- soil physical properties (aggregate stability - AS, erodibility ratio - ER, structure stability ratio - SSR, clay ratio - CR, percentage of sand, silt and clay), ii- soil chemical properties (soil reaction - $\mathrm{pH}$, electrical conductivity - EC, organic matter - $\mathrm{OM}$ and lime content - $\mathrm{CaCO}_{3}$ ), iii- macronutrient elements (total nitrogen - TN, available phosphorus - AvP, exchangeable potassium - exK, exchangeable calcium - exCa, exchangeable magnesium - exMg and exchangeable sodium - exNa), iv- micronutrient elements (available iron - AvFe, available manganese - AvMn, available zinc - AvZn, available copper - AvCu). Table 1 shows the selected analytical protocols.

In this study, due to variation of units of the indicators, a standard scoring function (SSF) (Andrews et al 2002) was used and scores ranging from 0 to 1 were attributed. Three types of indicators were separated according to their affiliation to soil quality, where the most desired soil functionality was associated with low, intermediate or high values (Liebig et al 2001): (1) "More is better" function (MB) was affiliated to $\mathrm{CaCO}_{3}$ content, clay content, clay ratio (CR), aggregate stability (AS) and structure stability index (SSI) considering structural stability, resistance to soil erosion, available water capacity and then organic matter OM content, macro- and micronutrient elements for their parts in soil fertility as their high content is favourable for sustainable tea cultivation. (2) "Less is better" function (LB) was affiliated to Na content, erodibility ratio (ER), dispersion ratio (DR), sand and silt content for their part in degradation of soils. (3) 
"Optimal range" function (OR) was affiliated to $\mathrm{pH}$ where scores were distributed using the both previous function types depending on whether the value of this indicator was lower or higher than the optimal range. The SSF equations (Andrews et al 2002) for the indicators were given in Table 2.

Table 1- Protocol measurements for indicators selected in the study

\begin{tabular}{|c|c|c|c|}
\hline Parameters & Unit & Protocol & Reference \\
\hline Aggregate stability (AS) & $\%$ & Wet sieving & Kemper \& Rosenau (1986) \\
\hline Dispersion ratio (DR) & $\%$ & $\mathrm{DR}=(\mathrm{a} / \mathrm{b}) * 100$ & Lal \& Elliot (1994) \\
\hline Erodibility ratio (ER) & $\%$ & $\mathrm{ER}=(\mathrm{a} / \mathrm{b}) *(\mathrm{~A} / \mathrm{c})^{*} 100$ & Lal \& Elliot (1994) \\
\hline Structure stability index (SSI) & $\%$ & $\mathrm{SSI}=\sum \mathrm{b}-\sum \mathrm{b}$ & Lal \& Elliot (1994) \\
\hline Clay ratio $(\mathrm{CR})$ & $\%$ & $C R=(100-c) / c$ & Bouyoucos (1935) \\
\hline Texture (Clay, Silt and Sand) & $\%$ & hydrometer method & Bouyoucos (1951) \\
\hline $\mathrm{OM}$ & $\%$ & Walkley-Black wet digestion & Nelson \& Sommers (1982) \\
\hline $\mathrm{pH}$ & $1: 2.5$ & (w:v) soil-water suspension & Soil Survey Laboratory (1992) \\
\hline EC & $\mathrm{dS} \mathrm{m}^{-1}$ & (w:v) soil-water suspension & Soil Survey Laboratory (1992) \\
\hline $\mathrm{CaCO}_{3}$ & $\%$ & Scheibler calcimeter & Soil Survey Staff (1993) \\
\hline $\mathrm{NaHCO}_{3}-\mathrm{P}$ & $\mathrm{mg} \mathrm{kg}^{-1}$ & Bray and Kurtz & Kacar (1994) \\
\hline Total N & $\%$ & Kjeldahl & Bremner \& Mulvaney (1982) \\
\hline NH4OAC-K, Ca, M, Na & $\mathrm{mg} \mathrm{kg}^{-1}$ & $\begin{array}{l}\text { Ammonium acetate extraction, } \\
\text { flame spectrometry detection }\end{array}$ & Soil Survey Laboratory (1992) \\
\hline DTPA-Cu, Fe, Mn, Zn & $\mathrm{mg} \mathrm{kg}^{-1}$ & DTPA extraction, AAS detection & Lindsay \& Norvell (1978) \\
\hline
\end{tabular}

Table 2- Standard scoring functions and parameters for soil indicators

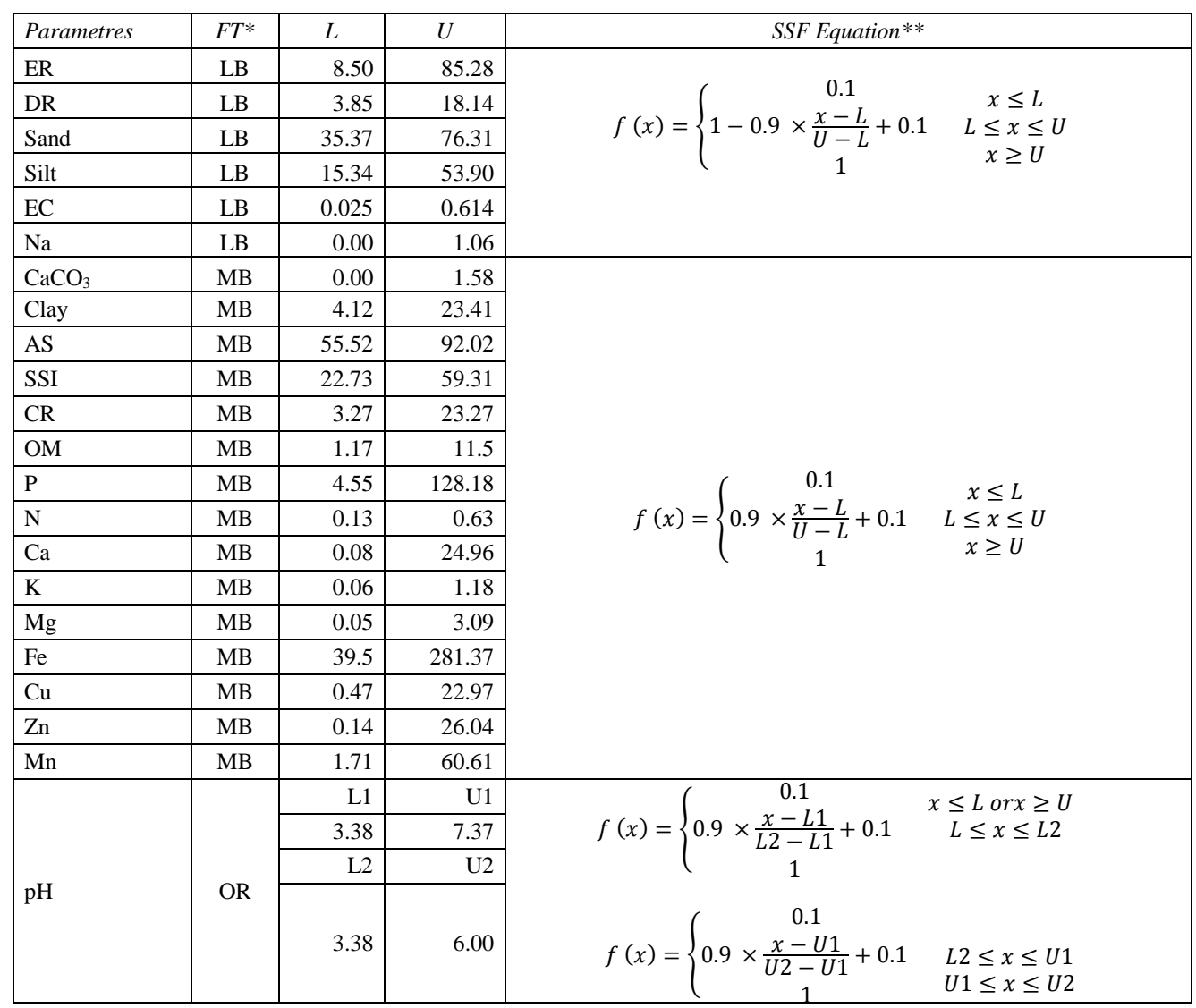

$*$, FT means function type; MB means more is better; LB, means low is better; OR, means optimal range; **SSF, means standard scoring function; in these three equations, $\mathrm{x}$ is the monitoring value of the indicator, $\mathrm{f}(\mathrm{x})$ is the score of indicators ranged between 0.1 and 1 , and $\mathrm{L}$ and $\mathrm{U}$ are the lower and the upper threshold value, respectively 


\subsection{Soil quality Index and weight assignment by Analytical Hierarchy Process}

Successful land cultivation and farming, generating diverse kinds of land utilization, is determined by environmental conditions, which can be described by set of soil and land quality indicators. Consequently, land mapping units can be described by a set of land characteristics, which are land and soil attributes affecting their suitability for certain land utilization types (Van Diepen et al 1991). Land utilization type in the present research is tea production. Soil requirements for tea cultivation including soil physical and chemical properties were determined based on literature (Kacar 1984; Özyazıcı et al 2010 and 2013; Saygın et al 2017). Soil characteristic indicators and weighting rates commonly used in tea growing soil quality assessment were applied to compile information on the study area; they are listed as follows: aggregate stability, erodibility ratio, structure stability ratio, clay ratio, percentage of sand, silt and clay, soil reaction, electrical conductivity, organic matter and lime content, total nitrogen, phosphorus, potassium, calcium, magnesium and sodium, iron, zinc, copper, and manganese. All indicators were scored and weighted, then soil quality indices were estimated for each soil sample using the following formula (1) (Doran \& Parkin, 1994);

$\mathrm{SQI}_{w}=\sum_{\mathrm{i}=1}^{\mathrm{n}}\left(\mathrm{W}_{i} \cdot \mathrm{X}_{i}\right)$

Where; $S Q I_{w}$ is tea soil quality index, $W_{i}$ is weighting of indictor $i, X_{i}$ is score of indictor $i$ obtained by $\mathrm{SSF}, n$ is number of indicator.

Land use suitability for the particular land use type is directly proportional to the SQI $\mathrm{w}_{\mathrm{w}}$ (Table 3 ). In this table, Class VI is the most suitable or excellent for tea plant, while classes I and II are not appropriate for tea cultivation in terms of soil quality (Da Silva et al 2015; Nabiollahi et al 2017).

Table 3- Soil quality index classes (Da Silva et al 2015; Nabiollahi et al 2017)

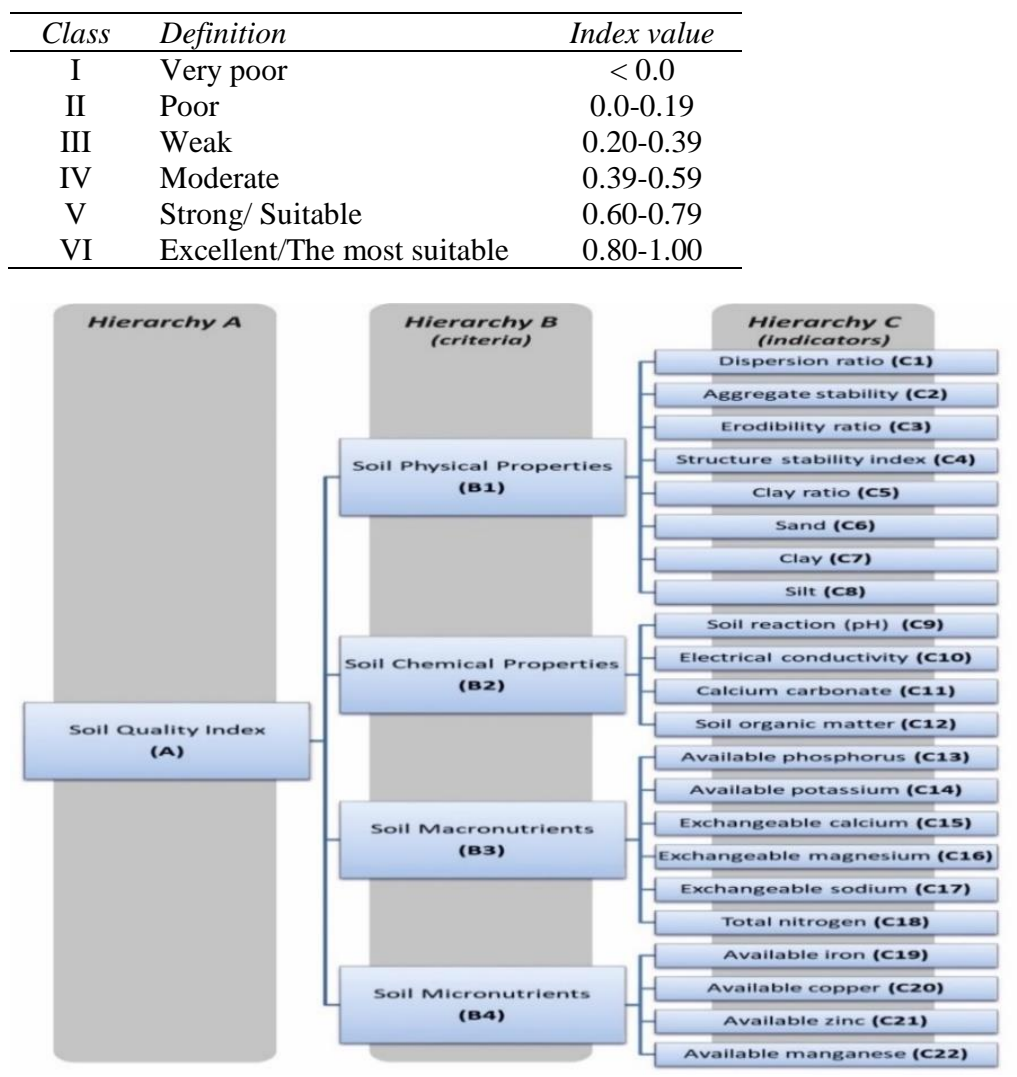

Figure 3- Hierarchical structure for the parameters' weight assignments 
A total of 22 soil quality indicators were grouped into 4 criteria: physical, chemical, macronutrients and micronutrients, which means A, B, and C matrices in the hierarchy were logically designed (Figure 3).

Each indicator (hierarchy $\mathrm{C}$ ) has an importance level that variously affects the land suitability for tea plant. The weighting process has to be carried out for both, hierarchy B and C, in order to learn also the importance level of criteria in Hierarchy B (Özyazıcı et al 2013).

In order to assign weights of indicators and criteria, Analytical Hierarchy Process according to Saaty (1980) was employed due to its capability to handle heterogeneous factors on multi-criteria decision level (Jiuquan et al 2015). The hierarchical structure makes possible to assess contribution of particular criteria at lower levels to higher-level criteria. Analytical Hierarchy Process (AHP) weighting utilizes the pairwise comparison matrix instead of taking expert opinions into consideration directly. Indicator weights $\left(\mathrm{W}_{\mathrm{i}}\right)$ were determined by judging two criteria against each other and assigning values from the scale between 9 and $1 / 9$ as described by Saaty (1980) and Table 4 . Some researchers such as Rezaei-Moghaddam \& Karami (2008) and Dengiz et al (2015) stated that the pairwise comparison simplifies the decision making process by independent assessment of the contribution of each criterion.

Table 4- The comparison scale in AHP (Saaty, 1980)

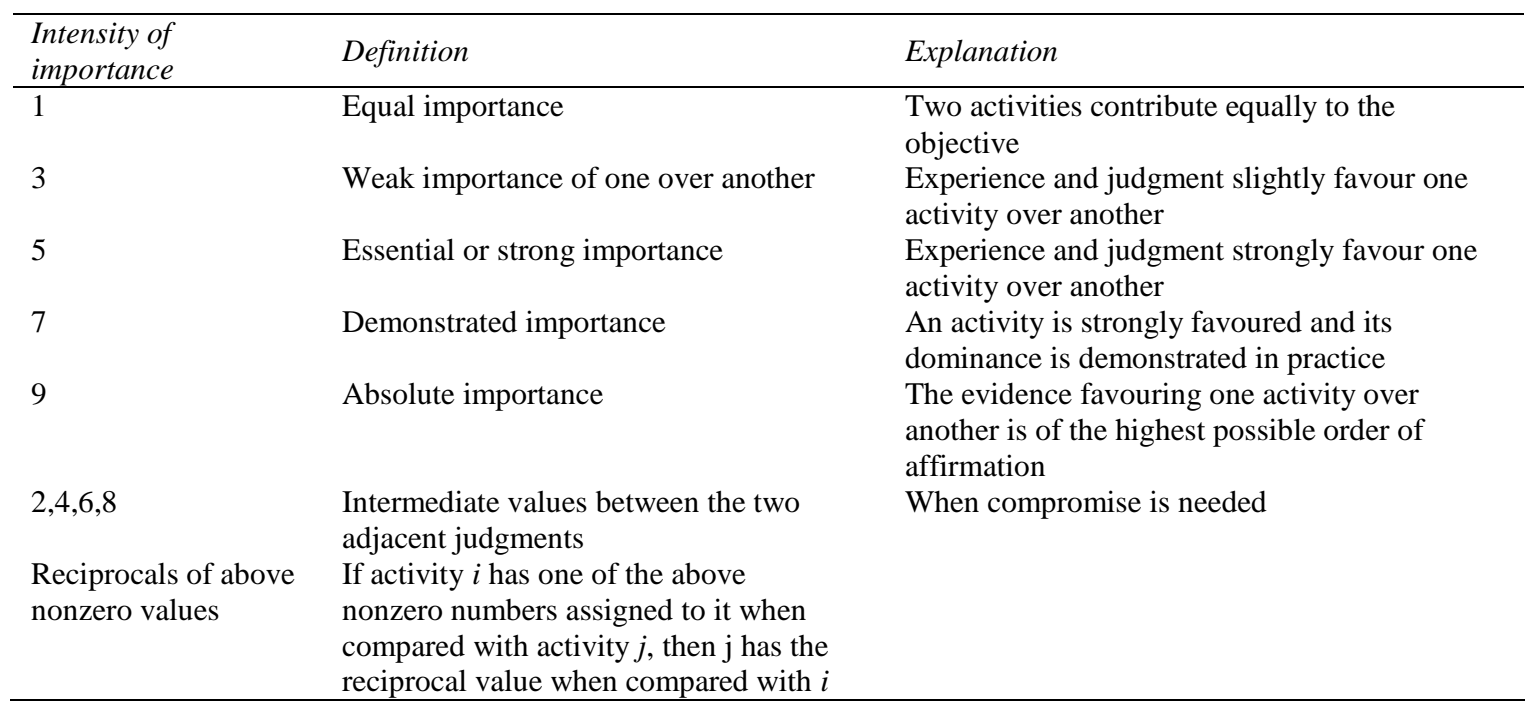

A square matrix was constructed from the pairwise comparisons of the indicators, normalized and weighted with respect to the indicators (details in Bhushan \& Rai 2004; Şener et al 2010; Dengiz et al 2015). After that, assessment of the matrix consistency was carried out. The consistency index, CI, was estimated as (2):

$\mathrm{CI}=\left(\lambda_{\max }-\mathrm{n}\right) /(\mathrm{n}-1)$

Where; CI, means the consistency index; $\lambda_{\max }$, means the highest principal eigenvalue of the matrix, and $n$ means the order of the matrix. Consistency ratio was then calculated (3):

\section{$\mathrm{CR}=\mathrm{CI} / \mathrm{RI}$}

Where; CR is the consistency ratio and RI, means the random index (see Table 5). Revision of the judgements is needed if CI failed to reach a threshold level. In general, a consistent matrix should have CR $\leq 0.1$.

Table 5- Values of Random index (RI) (Saaty, 1980)

\begin{tabular}{cccccccccccccccc}
\hline $\mathrm{n}$ & 1 & 2 & 3 & 4 & 5 & 6 & 7 & 8 & 9 & 10 & 11 & 12 & 13 & 14 & 15 \\
\hline $\mathrm{RI}$ & 0.00 & 0.00 & 0.58 & 0.90 & 1.12 & 1.24 & 1.32 & 1.41 & 1.45 & 1.49 & 1.51 & 1.48 & 1.56 & 1.57 & 1.59 \\
\hline
\end{tabular}

Tarım Bilimleri Dergisi - Journal of Agricultural Sciences 26 (2020) 42-53 


\section{Results and Discussion}

\subsection{Soil physico-chemical properties}

The physico-chemical characteristics of the 28 soil samples taken from the tea gardens in Ortaçay micro catchment of Rize province showed changefulness as a result of dynamic interactions among natural environmental factors, including the degree of soil formation, leaching process, and agricultural activities such as tillage systems or fertilization (Başkan et al 2017). Their descriptive statistical parameters are given in Table 6. According to Table 6, AS, DR, SSI, AvFe, sand and silt content showed normal distribution, whereas other parameters were found in unsymmetrical position called as skewness. Variability of the properties in terms of coefficient of variation $(\mathrm{CV})$ was classified as low $(<15 \%)$, medium $(15-35 \%)$ and moderate (>35\%) (Mallants et al 1996). In this case, AvP and AvFe showed very high variation (more than $100 \%$ ). Total $\mathrm{N}$ concentrations varied between $0.13 \%$ and $0.63 \%$ with the average of $0.30 \%$. The mean values of organic matter and $\mathrm{CaCO}_{3}$ content $(\%)$ were 0.15 and 5.39, respectively. Soil texture class slightly varied from sandy loam to loam and sandy clay loam. Clay content was between $4.12 \%$ and $23.41 \%$ and content of sand varied between $35.37 \%$ and $76.31 \%$. In addition, Table 6 shows also statistical distribution of micronutrient elements concentration. According to limit values of AvZn for tea plant reported in Lindsay \& Norvell (1978), FAO (2008) and Özyazıcı et al (2011), level of AvZn was found insufficient in most of the soil samples and its mean values was $3.53 \mathrm{mg} \mathrm{kg}^{-1}$. On the other hand, other micronutrient elements' concentrations were determined as sufficient. Finally, minimum and maximum values of SQI $\mathrm{w}_{\mathrm{w}}$ changed between 0.29 and 0.53 .

Table 6- Descriptive statistical analysis of physical and chemical properties of soil samples

\begin{tabular}{|c|c|c|c|c|c|c|c|c|}
\hline Parameters & Mean & $S D$ & $* C V$ & Variance & Min. & Max. & **Skewness & Kurtosis \\
\hline $\mathrm{AS}(\%)$ & 70.73 & 8.75 & 36.50 & 76.69 & 55.52 & 92.02 & 0.39 & 0.14 \\
\hline DR $(\%)$ & 10.31 & 4.19 & 14.29 & 17.63 & 3.85 & 18.14 & 0.25 & -0.89 \\
\hline $\mathrm{ER}(\%)$ & 29.86 & 18.28 & 76.78 & 334.16 & 8.50 & 85.28 & 1.64 & 3.02 \\
\hline SSI (\%) & 38.53 & 8.17 & 36.58 & 66.88 & 22.73 & 59.31 & 0.22 & 0.33 \\
\hline CR (\%) & 9.63 & 5.09 & 20.00 & 25.94 & 3.27 & 23.27 & 1.02 & 0.54 \\
\hline Sand (\%) & 56.89 & 9.34 & 40.94 & 87.30 & 35.37 & 76.31 & 0.13 & 0.00 \\
\hline Clay (\%) & 11.50 & 5.14 & 19.29 & 26.47 & 4.12 & 23.41 & 0.69 & -0.01 \\
\hline Silt (\%) & 31.60 & 7.97 & 38.56 & 63.55 & 15.34 & 53.90 & 0.47 & 1.19 \\
\hline $\mathrm{pH}(1: 2.5)$ & 4.34 & 0.94 & 3.99 & 0.89 & 3.38 & 7.37 & 1.69 & 3.02 \\
\hline $\mathrm{EC}\left(\mathrm{dS} \mathrm{m}^{-1}\right)$ & 0.29 & 0.15 & 0.59 & 0.02 & 0.03 & 0.61 & 0.64 & -0.59 \\
\hline $\mathrm{CaCO}_{3}(\%)$ & 0.15 & 0.28 & 1.49 & 0.07 & 0.10 & 1.59 & 5.29 & 28.00 \\
\hline OM $(\%)$ & 5.39 & 2.29 & 10.33 & 5.28 & 1.17 & 11.50 & 0.55 & 0.49 \\
\hline $\mathrm{AvP}\left(\mathrm{mg} \mathrm{kg}^{-1}\right)$ & 48.23 & 35.71 & 123.63 & 1275.77 & 4.55 & 128.18 & 0.79 & -0.45 \\
\hline exK $\left(\mathrm{mg} \mathrm{kg}^{-1}\right)$ & 0.35 & 0.28 & 1.12 & 0.08 & 0.06 & 1.18 & 1.36 & 1.48 \\
\hline $\operatorname{exCa}\left(\mathrm{mg} \mathrm{kg}^{-1}\right)$ & 4.13 & 6.71 & 24.88 & 45.09 & 0.08 & 24.96 & 2.08 & 3.80 \\
\hline $\operatorname{exMg}\left(\mathrm{mg} \mathrm{kg}^{-1}\right)$ & 0.87 & 0.90 & 3.04 & 0.82 & 0.05 & 3.09 & 1.36 & 0.82 \\
\hline $\operatorname{exNa}\left(\mathrm{mg} \mathrm{kg}^{-1}\right)$ & 0.19 & 0.28 & 1.06 & 0.07 & 0.00 & 1.06 & 1.82 & 2.72 \\
\hline $\mathrm{TN}(\%)$ & 0.30 & 0.11 & 0.50 & 0.01 & 0.13 & 0.63 & 0.67 & 0.99 \\
\hline $\mathrm{AvFe}\left(\mathrm{mg} \mathrm{kg}^{-1}\right)$ & 146.36 & 63.86 & 241.87 & 4078.56 & 39.50 & 281.37 & 0.07 & -0.78 \\
\hline $\mathrm{AvCu}\left(\mathrm{mg} \mathrm{kg}^{-1}\right)$ & 2.91 & 4.41 & 22.50 & 19.46 & 0.47 & 22.97 & 3.96 & 17.00 \\
\hline $\operatorname{AvZn}\left(\mathrm{mg} \mathrm{kg}^{-1}\right)$ & 3.53 & 5.52 & 25.90 & 30.53 & 0.14 & 26.04 & 3.21 & 10.95 \\
\hline $\operatorname{AvMn}\left(\mathrm{mg} \mathrm{kg}^{-1}\right)$ & 17.05 & 13.94 & 58.90 & 194.35 & 1.71 & 60.61 & 1.31 & 1.94 \\
\hline $\mathrm{SQI}_{\mathrm{w}}$ & 0.42 & 0.06 & 0.24 & 0.00 & 0.29 & 0.53 & -0.70 & 0.06 \\
\hline
\end{tabular}

SD, Standard deviation; Min., Minimum; Max., Maximum; n, sample number; *CV, (Coefficient of Variation): < 15 = Low variation; $15-35=$ Moderate variation; $>35=$ High variation; $* *$ skewness: $<|\mp 0.5|=$ Normal distribution; $0.5-1.0=$ Application of character changing for dataset, and $>1,0 \rightarrow$ application of Logarithmic change

\subsection{Computation of soil quality index}

According to the approach of Doran \& Jones (1996), in order to start the calculation of a SQI ${ }_{w}$ firstly soil quality indicators were defined as the processes and features of the soil which are sensitive to variability induced by both natural and artificial indicators. Therefore, soil quality indicators can be divided as either inherent or dynamic. The inherent indicators are for example particle size distribution or mineral 
composition, while the dynamic ones reflect soil conditions resulting from current agrotechnology. In this case Wienhold et al (2004) pointed out that dynamic indicators are used to evaluate how soil management decisions affect soil properties. This approach established in total 22 soil quality indicators enabling to reflect main effects as a result of agriculture management practices and inherent characters of soil for the tea plant.

Weightings were assigned to each soil sample as follows. Firstly, AHP approach was performed to determine eigenvector values. In this step the consistency ratio was determined far below the highest value at which the weighting could be called consistent, which is 0.1. Success of the AHP succeeded in weighting was reported also by Wali et al (2016). Contribution weights of soil indicators to the SQI ${ }_{\mathrm{w}}$ estimated by the AHP were given in Table 7. The highest value $(0.369)$ was determined for hierarchy B1 (soil physical indicators) whereas, the lowest value (0.126) was found for hierarchy B4 (soil micronutrient elements concentration). In addition, the highest values of indicators for each hierarchy B1, B2, B3 and B4 were calculated for AS (0.315), OM (0.400), TN (0.405) and AvFe (0.053), respectively.

Table 7- Contribution weight of soil indicators to soil quality calculated by the AHP

\begin{tabular}{|c|c|c|c|c|c|}
\hline \multicolumn{6}{|l|}{ Hierarchy $A$} \\
\hline \multirow{3}{*}{ Hierarchy $C$} & \multicolumn{4}{|c|}{ Hierarchy $B$} & \multirow{3}{*}{$\begin{array}{l}\text { Combined weight } \\
\qquad \sum \mathrm{B}_{i} \times \mathrm{C}_{i}\end{array}$} \\
\hline & B1 & B2 & B3 & B4 & \\
\hline & 0.369 & 0.299 & 0.206 & 0.126 & \\
\hline DR (\%) & 0.076 & & & & 0.028 \\
\hline $\operatorname{AS}(\%)$ & 0.315 & & & & 0.116 \\
\hline ER $(\%)$ & 0.129 & & & & 0.048 \\
\hline SSI (\%) & 0.109 & & & & 0.040 \\
\hline CR (\%) & 0.095 & & & & 0.035 \\
\hline Sand $(\%)$ & 0.066 & & & & 0.024 \\
\hline Clay (\%) & 0.125 & & & & 0.046 \\
\hline Silt (\%) & 0.085 & & & & 0.031 \\
\hline $\mathrm{pH}(1: 2.5)$ & & 0.207 & & & 0.062 \\
\hline $\mathrm{EC}\left(\mathrm{dS} \mathrm{m^{-1 }}\right)$ & & 0.071 & & & 0.021 \\
\hline $\mathrm{CaCO}_{3}(\%)$ & & 0.322 & & & 0.096 \\
\hline $\mathrm{OM}(\%)$ & & 0.400 & & & 0.120 \\
\hline $\operatorname{AvP}\left(\mathrm{mg} \mathrm{kg}^{-1}\right)$ & & & 0.252 & & 0.052 \\
\hline $\operatorname{AvK}\left(\mathrm{mg} \mathrm{kg}^{-1}\right)$ & & & 0.154 & & 0.032 \\
\hline $\mathrm{exCa}\left(\mathrm{mg} \mathrm{kg}^{-1}\right)$ & & & 0.082 & & 0.017 \\
\hline $\operatorname{exMg}\left(\mathrm{mg} \mathrm{kg}^{-1}\right)$ & & & 0.076 & & 0.016 \\
\hline $\operatorname{exNa}\left(\mathrm{mg} \mathrm{kg}^{-1}\right)$ & & & 0.031 & & 0.006 \\
\hline $\mathrm{TN}(\%)$ & & & 0.405 & & 0.083 \\
\hline $\operatorname{AvFe}\left(\mathrm{mg} \mathrm{kg}^{-1}\right)$ & & & & 0.421 & 0.053 \\
\hline $\mathrm{AvCu}\left(\mathrm{mg} \mathrm{kg}^{-1}\right)$ & & & & 0.099 & 0.012 \\
\hline $\operatorname{AvZn}\left(\mathrm{mg} \mathrm{kg}^{-1}\right)$ & & & & 0.359 & 0.045 \\
\hline $\operatorname{AvMn}\left(\mathrm{mg} \mathrm{kg}^{-1}\right)$ & & & & 0.121 & 0.015 \\
\hline Total & 1 & 1 & 1 & 1 & 1 \\
\hline
\end{tabular}

These results can be called consistent and the highest value of hierarchy B1 can be explained. Most of the tea plantations in this catchment have been located on steep hillsides. In addition, this area receives more than $2300 \mathrm{~mm}$ annual precipitations. Therefore, these areas are under potentially high risk in terms of soil erosion, particularly in tea cultivation or management period. For that reason, soil erodibility factors or erosion sensitivity parameters such as aggregate stability, dispersion ratio and others, which show soil resistance to erosion, were determined. Moreover, soil texture selected as physical parameter is also significant in terms of soil physical, chemical and biological effects on tea plant growth. On the other hand, other indicators can be arranged by management practices such as $\mathrm{pH}$ regulation by adding lime to supply tea plant's requirements onto soil reaction and elimination of insufficient macro- or micronutrient elements by fertilization.

In hierarchy B2, OM obtained the highest value due to its inevitable importancy as well as for its effect on biological and physico-chemical soil properties. This indicator is at the same time contained in lowering 
of erosion risks, storage and supply of nutrient elements, overall improvement of soil fertility and affects cation exchange capacity, too. On the other hand, this indicator can be affected by soil and tea crop management practices. The tea plant cannot grow in strong acid conditions such as $\mathrm{pH}<4$ (Saygin et al 2017), but reaction of some of the soil samples was lower than 4. According to values of EC, all soil samples were described as nonsaline due to high leaching process and found as the lowest weight value in B2 hierarchy.

As for hierarchy B3, the highest weight values were found for the main macronutrient elements total nitrogen (0.405) and available phosphorus (0.252). Although soil fertility and yields were significantly improved by intensification of management practices, unfavourable environmental impacts can be observed in the catchment, such as soil acidification induced by enormous application of mineral fertilizers, especially nitrogen, and decreased use of organic fertilizers. Particularly, Acrisol-Alisol great soil group which has low base capacity has $\mathrm{pH}<5$. For that reason, nitrogen fertilizers such as calcium ammonium nitrate should be used. Finally, the lowest weight value belongs to hierarchy B4. Sufficient amount of available micronutrient elements was determined in all soils except AvZn which was found low in soil samples No. 4, 8, 9, 13, 18, 22, and 25 .

Secondly, score values of all indicators were determined by using the best soil functionality and were joined with high, low or moderate (optimal range) values ranging between 0 and 1 based on their function on soil quality. Finally, after assigning the eigenvector for each indicator and determining the scoring values, weighted linear combination technique was employed to estimate the $S Q I_{w}$ values for individual soil samples.

The assessment of results, taking into consideration the six $\mathrm{SQI}_{\mathrm{w}}$ classes (Table 3), showed that mostly moderate quality soils (Class IV) were dominant with $75 \%$ of the total soil samples in the catchment, whereas $25 \%$ of soil samples were found weak (Class II) in terms of soil quality. Samples with excellent or strong (Class VI and Class V) and poor or very poor quality (Class II and IV) did not match the established criteria (Table 8).

In this respect, samples can be separated into two various soil quality classes due to soil heterogeneity. (1) The sandy loam and loamy sand, weak quality soils, which closely correspond with the Leptosol were found on the steep slope land. Quality of such soils in the study area is significantly limited by low OM, water retention and too low soil $\mathrm{pH}$ for tea cultivation; (2) the loamy clay and sandy clay loam, moderate quality soil located on generally Alisol-Acrisol great soil groups. Although some soils (samples 9 and 23) have higher content of OM, soil quality was classified as weak due to low resistance capacity for soil erosion and insufficient nutrient elements.

Table 8- Soil quality index values of each soil sample for tea plant

\begin{tabular}{|c|c|c|c|c|c|c|c|c|c|c|c|}
\hline \multirow{2}{*}{$\begin{array}{c}\text { Sample } \\
\text { no }\end{array}$} & \multicolumn{2}{|c|}{ Coordinate } & \multirow{2}{*}{$\begin{array}{c}\text { Land } \\
\text { use }\end{array}$} & \multicolumn{2}{|c|}{ Soil quality } & \multirow{2}{*}{$\begin{array}{c}\text { Sample } \\
\text { no }\end{array}$} & \multicolumn{2}{|c|}{ Coordinate } & \multirow{2}{*}{$\begin{array}{l}\text { Land } \\
\text { use }\end{array}$} & \multicolumn{2}{|c|}{ Soil quality } \\
\hline & East & North & & Index & Class & & East & North & & Index & Class \\
\hline 1 & 633392 & 4533243 & tea & 0.465 & 4 & 15 & 641558 & 4533520 & tea & 0.436 & 4 \\
\hline 2 & 638413 & 4534658 & tea & 0.295 & 3 & 16 & 641158 & 4542516 & tea & 0.501 & 4 \\
\hline 3 & 636883 & 4536169 & tea & 0.296 & 3 & 17 & 643199 & 4544209 & tea & 0.506 & 4 \\
\hline 4 & 635391 & 4536169 & tea & 0.428 & 4 & 18 & 640129 & 4543548 & tea & 0.449 & 4 \\
\hline 5 & 639141 & 4533119 & tea & 0.483 & 4 & 19 & 638000 & 4542408 & tea & 0.287 & 3 \\
\hline 6 & 638473 & 4531436 & tea & 0.433 & 4 & 20 & 639589 & 4541933 & tea & 0.423 & 4 \\
\hline 7 & 640047 & 4535351 & tea & 0.470 & 4 & 21 & 640784 & 4544289 & tea & 0.503 & 4 \\
\hline 8 & 636645 & 4538572 & tea & 0.359 & 3 & 22 & 644450 & 4541011 & tea & 0.402 & 4 \\
\hline 9 & 638403 & 4540207 & tea & 0.434 & 4 & 23 & 645845 & 4540864 & tea & 0.365 & 3 \\
\hline 10 & 638661 & 4537992 & tea & 0.422 & 4 & 24 & 644965 & 4538697 & tea & 0.369 & 3 \\
\hline 11 & 639987 & 4536643 & tea & 0.461 & 4 & 25 & 643063 & 4540704 & tea & 0.367 & 3 \\
\hline 12 & 641242 & 4536520 & tea & 0.459 & 4 & 26 & 644580 & 4543115 & tea & 0.524 & 4 \\
\hline 13 & 642587 & 4535734 & tea & 0.464 & 4 & 27 & 642805 & 4542625 & tea & 0.428 & 4 \\
\hline 14 & 644799 & 4534084 & tea & 0.405 & 4 & 28 & 640760 & 4540941 & tea & 0.429 & 4 \\
\hline
\end{tabular}




\section{Conclusions}

Soil quality evaluation presents a useful tool for agriculture managers and policy makers to obtain a better understanding of the influence of different agricultural systems onto soil resources. Because, the used model collected all related soil indicators into consideration and reflected the most consistent and logical results. Soil quality of Ortaçay Catchment in Rize province, a typical tea (Camellia sinensis L.) growing area located in east part of Black Sea Region, was assessed using soil quality index ( $\left.\mathrm{SQI}{ }_{w}\right)$ method. Twenty two indicators were grouped into 4 criteria (soil physical, chemical properties, micro- and macronutrient status of soils) by taking into consideration their effects on tea plant after taking 28 representative soil samples from the study area. According to soil quality assessment results, poor, very poor, strong and excellent soil quality classes for tea plant were not detected in the study area. Most of the soil samples' quality showed moderate level and rest of them have weak quality due to a propensity for soil erosion or other problems such as course texture or insufficient nutrient elements. For that reason, some biophysical measures to increase soil quality level by creating optimum tea plant growing medium should be taken such as liming, application of suitable fertilization program, increasing of resistance to soil erodibility. Moreover, the present monitoring of soil quality gives future opportunity to evaluate the system of land management for tea cultivation in humid and sub-humid terrestrial ecosystem. For further monitoring of soil quality in similar areas, some land properties such as soil depth and slope should be considered as well.

\section{References}

Andrews S S, Karlen D L \& Mitchell J P (2002). A comparison of soil quality indices methods for vegetable production system in northern California. Agriculture, Ecosystems and\& Environment 90: 25-45

Bhushan N \& Rai K (2004). Strategic Decision Making: Applying the Analytic Hierarchy Process. Springer-Verlag, New York, pp. 172

Bouyoucos G J (1935). The clay ratio as a criterion of soils to erosion. Journal of the American Society of Agronomy 27: 738-751

Bouyoucos G J (1951). A recalibration of the hydrometer method for making mechanical analysis of soils. Agronomy Journal 43: 435-438

Baskan O, Dengiz O \& Demirag İ T (2017). The land productivity dynamics trend as a tool for land degradation assessment in a dryland ecosystem. Environmental Monitoring and Assessment 189 (212): 3-21

Candemir F \& Gülser C (2011). Effects of different agricultural wastes on some soil quality indexes at clay and loamy sand fields. Communications in Soil Science and Plant Analysis 42: 13-28

Da Silva A F, Barbosa A P, Zimback C R L, Landim P M B \& Soares A (2015). Estimation of croplands using indicator kriging and fuzzy classification. Computers and Electronics in Agriculture 111: 1-11

Dengiz O, Özyazıcı M A \& Sağlam M (2015). Multi-Criteria assessment and geostatistical approach for determination of rice growing suitability sites in Gokirmak catchment. Paddy Water Environment 13: 1-10. DOI 10.1007/s10333013-0400-4

Demir Z \& Gülser C (2015). Effects of rice husk compost application on soil quality parameters in greenhouse conditions. Eurasian Journal of Soil Science 4(3):185-190

Doran J W \& Parkin B T (1994). Defining and assessing soil quality. In: Doran, J.W., Coleman, D.C., Bezdicek, D.F., Stewart, B.A. (Eds.), Defining Soil Quality for a Sustainable Environment. Soil Science Society of America Inc., Madison, WI, USA, pp. 3-21 (SSSA Special Publication No. 35)

Doran J W \& Jones A J (1996). Methods for Assessing Soil Quality. SSSA Special Publication No. 49. Soil Science Society of America, Madison, Wisc

FAO (2008). Guide to laboratory establishment for plant nutrient analysis. FAO Fertilizer and Plant Nutrition Bulletin, No: 19, FAO: Rome, Italy

Tarım Bilimleri Dergisi - Journal of Agricultural Sciences 26 (2020) 42-53 
FAO (2009). FAOSTAT-Tea Production 2009; FAO: Rome, Italy

Gülser C (2004). A Comparison of some physical and chemical soil quality indicators influenced by different crop species. Pakistan Journal of Biological Sciences 7: 905-911

Gülser C, Kızılkaya R, Aşkın T \& Ekberli İ (2015). Changes in Soil Quality by Compost and Hazelnut Husk Applications in a Hazelnut Orchard. Compost Science and Utilization 23(3): 135-141

Jiuquan Z, Su Y, Wu J \& Liang H (2015). GIS based land suitability assessment for tobacco production using AHP and fuzzy set in Shandong province of China. Computers and Electronics in Agriculture 114: 202-211

Kacar B (1984). Çayın gübrelenmesi. Çay İşletmeleri Genel Müdürlüğü, Çay-Kur Yayını No: 4, Ankara, pp. 356

Kacar B (1994). Chemical Analysis of Soil and Plant (III), Ankara pp. 229-233

Karlen D L, Andrews S S \& Doran J W (2001). Soil quality: Current concepts and applications. Advances in Agronomy 74: $1-40$

Kemper W D \& Rosenau R C (1986). Aggregate stability and size distribution. Editor: Klute, A Methods of Soil Analysis, Part I-Physical and Mineralogical Methods, $2^{\text {nd }}$ ed., Soil Science Society of America Book Series No: 5 , SSA and ASA, Madison, Wisconsin, pp. 425-442

Lal R \& Elliot W (1994). Erodibility and erosivity. In R. Lal (Ed.), Soil Erosion Research Methods (2 ${ }^{\text {nd }}$ ed.), Delray Beach: St. Lucie Press, pp. 181- 210

Liebig M A, Varvel G E \& Doran J W (2001). A simple performance-based index for assessing multiple agroecosystem functions. Agronomy Journal 93: 313-318

Lindsay W L \& Norvell W A (1978). Development of a DTPA soil test for zinc, iron, manganese and copper. Soil Science Society of America Journal 42: 421-428

Mallants D, Mohanty B P, Jacques D \& Feyen J (1996). Spatial variability of hydraulic properties in a multi-layered soil profile. Soil Science 161: 167-181

Müftüoğlu N M (1987). Determination of Acidification of Tea Soils by various periods and methods and Evaluation of the Data Obtained. General Directorate of Tea Enterprises. Head of the Institute of Tea, Study Report of 1986, Rize, Turkey. 178-190 (in Turkish)

Müftüoğlu N M, Yüce E, Turna T, Kabaoğlu A, Özer S P \& Tanyel G (2010). The evaluation of some properties of tea soils in the Eastern Black Sea Region. Journal of Ege University Faculty of Agriculture. $5^{\text {th }}$ Plant Nutrition and Fertilization Cong. 3-7 June 2010. Proc. pp. 63-67

Nabiollahi K, Taghizadeh-Mehrjardi R, Kerry R \& Moradian S (2017). Assessment of soil quality indices for saltaffected agricultural land in Kurdistan Province, Iran. Ecological Indicators 83: 482-494

Nelson D W \& Sommers L E (1982). Total carbon, organic carbon and organic matter. In L. A. Page, R. H. Miller, \& D. R. Keeney (Eds.), Methods of soil analysis, part 2. Chemical and microbiological methods ( $2^{\text {nd }}$ ed.,), American Society of Agronomy, Madison, Wisconsin, pp. 539-579

Özcan H, Dengiz O \& Erşahin S (2017). Soils of Turkey (ed: Kapur, S., Akça, E., Günal, H). Alisols-Acrisols. World Soils Book Series, Springer, pp. 207-215

Özyazıcı G, Özyazıcı M A, Özdemir O \& Sürücü A (2010). Some physical and chemical properties of tea grown soils in Rize and Artvin provinces. Anadolu Journal of Agricultural Sciences 25: 94-99

Özyazıcı M A, Özyazıcı G \& Dengiz O (2011). Determination of micronutrients in tea plantations in the eastern Black Sea Region, Turkey. African Journal of Agricultural Research 6: 5174-5180

Özyazıcı M A, Dengiz O \& Aydoğan M (2013). Çay yetiştirilen tarım topraklarının reaksiyon değişimleri ve alansal dağılımları. Journal of Soil and Water 2: 23-29 
Qi Y, Darilek Huang J L, Zhao B, Sun Y \& Gu Z (2009). Evaluating soil quality indices in an agricultural region of Jiangsu Province, China. Geoderma 149: 325-334

Rezaei-Moghaddam K \& Karami E (2008). A multiple criteria evaluation of sustainable agricultural development models using AHP. Environment, Development and Sustainability 10: 407-426

Saaty T (1980). The Analytic Hierarchy Process. McGraw-Hill, New York, USA. 287

Saygın F, Gürsoy F E, Demirağ Turan İ \& Dengiz O (2017). Çataklı çayı havzası doğu yakasında çay tarımı yapılan toprakların fiziksel, kimyasal ve verimlilik özelliklerinin belirlenmesi. Türkiye Tarımsal Araştırmalar Dergisi 4: $143-154$

Şener Ş, Şener E, Nas B \& Karagüzel R (2010). Combining AHP with GIS for landfill site selection: A case study in the Lake Beyşehir catchment area (Konya, Turkey). Waste Management 30: 2037-2046

Soil Survey Laboratory (1992). Procedures for collecting soil samples and methods of analysis for soil survey. Soil Surv. Invest. Rep. I. U.S. Gov. Print. Office, Washington D.C. USA

Soil Survey Staff (1993). Soil Survey Manuel. USDA Handbook. No: 18, Washington D.C. USA

Van Diepen C A, van Keulen H, Wolf J \& Berkhout J A A (1991). Land evaluation: from intuition to quantification. In: Advances in Soil Science (Ed. BA Stewart). Springer, New York, USA, pp. 139-204

Wali E, Datta A, Shrestha R P \& Shrestha S (2016). Development of a land suitability model for saffron (Crocus sativus L.) cultivation in Khost Province of Afghanistan using GIS and AHP techniques. Archives of Agronomy and Soil Science 62: 921-934

Wienhold B J, Andrews S S \& Karlen D L (2004). Soil Quality: A Review of the Science and Experiences in the USA. Journal of Environmental Geochemistry and Health 26: 89-95 